Interferon and Its Clinical Potential. By D. A. J. Tyrrell. Pp. viii +104. (Heinemann Medical: London, 1976.) $£ 3.50$.

THIS brief and timely monograph clearly presents the author's personal views of the interferon area. The 91page review covers two decades of intensive research which has formed the basis for the present clinical investigations involving interferon, following its discovery in 1957. This remarkable molecule is not only of clinical interest as an anti-viral, but there is an emerging body of information supporting its role as a locally active cell regulator with a broad range of functions beyond its anti-viral action. It not only seems to influence malignant, immune and haematopoietic cell division, but certain specialised cell biosynthetic functions as well. This viral inhibitor discovered by Alick Isaacs now also attracts the efforts of molecular biologists as cell-free systems have been developed in which it can be produced and in which anti-viral action can be demonstrated. The recent discovery of cell membrane receptors for interferon, which seem to be gangliosides, should now allow elucidation of the mechanism of the first step in its action-that is, its binding to cells.

The book provides the clinician, basic virologist, and specialised investigator with a firm basis for understanding the potential of interferon in human medicine. It is digestable in an evening of solid reading by anyone with an understanding of modern biology. Although clinical trial results are appearing with greater frequency and views on its mechanism of action will be sharpened as more is learned of the fundamentals of viral replication, the basic description of the interferon system presented in this volume will be useful to future investigators.

The enthusiasm of the writer and his clear style of writing leads the reader through the voluminous recent literature in this area. One hundred and sixty-five carefully selected references are used to support a very readable discussion of interferon action and production in cell culture, animal models and human disease settings. Present concepts of the assay, properties and purification of interferon are also dis-

cussed. A number of well cast tables and easy-to-comprehend diagrams aid the reader in following the text. The methods for preparation and purification of human leukocyte interferon for clinical use, developed in Finland and in the UK, are discussed by the author, who was chairman of the UK Scientific Committee on Interferon, a group which planned and supported much of the early work with the material. The

\title{
Arroyos in the American South-West
}

Arroyos and Environmental Change in the American South-West. By R. U. Cooke and R. W. Reeves. Pp. xii 213. (Clarendon: Oxford, 1976.) $£ 8.50$.

LARGE gullies with near vertical walls and flat, sandy bottoms, dissecting the alluvial valley floors of the American South-West, have attracted the attention of geologists and geographers for several decades. The arroyos, as they are called, seem to have developed after 1850 , about the time of white settlement and the introduction of livestock in large numbers to the western plains. Not unnaturally, it was commonly supposed that land-use changes were responsible for the erosion, on account of depletion of the vegetation and greater runoff. Sedimentary sections showed, however, that there had been earlier periods of trenching in prehistoric times, and it was suggested that slight climatic changes were at least partly responsible.

It is known that overstocking occurred in Arizona about the same time as severe drought in the $1880 \mathrm{~s}$, and it is clear from J. R. Hastings and R. M. Turner in The Changing Mile (University of Arizona, Tucson, 1965) and from other sources that the vegetation has deteriorated markedly since that time. Cooke and Reeves show that in the coastal regions of southern California where arroyos also occur, rainfall records provide no support for the idea that secular or cyclic changes in precipitation have played a determining role in the formation of the arroyos. Furthermore, they present evidence that calls into question much that is commonly accepted about the effects long experience of the author in this area insures the reader that the book accurately presents the basic biology of the interferon system, together with present accomplishments and perspectives for its use as a clinical anti-viral and anti-tumour agent.

T. C. Merigan is Professor of Medicine and Head of the Division of Infectious Diseases at Stanford University School of Medicine, Stanford, California. of land-use on runoff coefficients.

Using archival records of various kinds, and in particular the field notebooks of the US General Land Office surveyors, Cooke and Reeves trace the development of a large number of individual arroyos. As they acknowledge, the extension of certain Californian arroyos was documented by W. B. Bull ( $A$ m. J. Sci. 262, 249-258; 1964). Their own study is much more extensive. It demonstrates that wherever the history of an arroyo can be traced, individual events and acts of interference by man have been responsible for its initiation and enlargement. Cultivation of valley floors and destruction of vegetation along shallow watercourses have usually played an important part; but in the case of the San Simon arroyo, for example, a wagon route seems to have been the immediate cause of gullying, whereas the Santa Cruz arroyo was initiated by water supply channels. Elsewhere, concentration of drainage water by culverts or other man-made features started the downcutting.

Arroyos have destroyed floodplains, accentuated flood peaks and accelerated sedimentation to the detriment of the environment of the American South-West. We now know that they are the outcome of a multitude of individual events and that sweeping explanations are inadequate. Cooke and Reeves have labouriously but effectively sawn through the Gordian knot tied by earlier investigations.

\section{A. T. Grove}

A. T. Grove is Lecturer in the Department of Geography at the University of Cambridge, UK. 